\title{
Storm clouds gather over leaked climate e-mails
}

The online publication of sensitive e-mails and documents from a British climate centre is brewing into one of the scientific controversies of the year, causing dismay among affected institutes and individuals. The tone and content of some of the disclosed correspondence are raising concerns that the leak is damaging the credibility of climate science on the eve of the United Nations climate summit in Copenhagen in December.

The Climatic Research Unit (CRU) at the University of East Anglia (UEA) in Norwich confirmed on 20 November that it had had more than 1,000 e-mails and documents taken from its servers, but it has not yet confirmed how much of the published material is genuine. "This information has been obtained and published without our permission," says Simon Dunford, a spokesman for the UEA, adding that the university will undertake an investigation and has already involved the police.

Many scientists contacted by Nature doubt that the leak will have a lasting impact, but climate-sceptic bloggers and mainstream media have been poring over the posted material and discussing its contents. Most consist of routine e-mail exchanges between researchers. But one e-mail in particular, sent by CRU director Phil Jones, has received attention for its use of the word "trick" in a discussion about the presentation of climate data. In a statement, Jones confirmed that the e-mail was genuine and said: 'The word 'trick' was used here colloquially as in a clever thing to do. It is ludicrous to suggest that it refers to anything untoward."

"If anyone thinks there's a hint of tweaking the data for nonscientific purposes, they are free to produce an analysis showing that Earth isn't warming," adds Michael Oppenheimer, a climate scientist and policy researcher at Princeton University in New Jersey. "In fact, they have been free to do so for decades and haven't been able to."

"There are apparently lots of people who really do think that global warming is an evil socialist plot, and that many scientists are part of the plot and deliberately faking their science," adds Tom

Wigley, a senior scientist at the

National Center for Atmospheric

Research in Boulder, Colorado, and former director of CRU.

Alleged e-mails containing critical remarks about other climate scientists are merely proof of lively debate in the community, adds

\section{"There are apparently lots of people who really do think that global warming is an evil socialist plot."}

Gavin Schmidt, a climate researcher with NASA's Goddard Institute for Space Studies in New York City.

The title of the uploaded file containing the leaked e-mails 'FOIA.zip' - has led to speculation that the affair may be linked to the deluge of requests for raw climate data that have recently been made under the UK Freedom of Information Act to Jones (see Nature 460, 787; 2009). The source of many of those requests is Steve McIntyre, the editor of Climate Audit, a blog that investigates the statistical methods used in climate science. "I don't have any information on who was responsible," McIntyre told Nature.

Nevertheless, e-mails allegedly sent by Jones seem to illustrate his reluctance to comply with these requests. "All scientists have the right to request your data and to try to falsify your results," says Hans von Storch, director of the Institute for Coastal Research in Geesthacht, Germany. "I very much respect Jones as a scientist, but he should be aware that his behaviour is beginning to damage our discipline." In a statement, the UEA said: "The raw climate data which has been requested belongs to meteorological services around the globe and restrictions are in place which means that we are not in a position to release them. We are asking each service for their consent for their data to be published in future."

However, von Storch believes that, at least until the affair is resolved, Jones should cease reviewing climate science for the Intergovernmental Panel on Climate Change.

Quirin Schiermeier

\section{Indian neutrino lab site rejected}

India's particle physicists have lost their battle to build a neutrino laboratory - one of the country's biggest physics projects under the Nilgiri hills at Singara in the state of Tamil Nadu. The government has upheld conservationists' view that its construction would endanger wildlife in the Nilgiri Biosphere Reserve (NBR), an important tiger and elephant habitat.

The 6.8-billion rupee (US\$150 million) India-based Neutrino Observatory (INO) has been mired in environmental controversy since 2006, but physicists were hoping it would be resolved in their favour (see Nature 461, 459; 2009). However, on 20 November India's minister of environment and forests, Jairam Ramesh, informed the scientists that they should not proceed at Singara.

Ramesh wrote that he was acting on a "large number of reports" received against the proposed site and the "very weighty reasons" put forward by Rajesh Gopal, head of forestry in his ministry. Ramesh has suggested the project consider instead a site near Suruliyar, also in Tamil Nadu, that does not pose Singara-type problems.

"Everybody in the INO project is disappointed," says project spokesman Naba Mondal, a physicist at the Tata Institute of Fundamental Research in Mumbai. Project scientists had already considered and rejected the potential site at Suruliyar because there were less available data on the characteristics of the rock that would need to be blasted out to create a cavern to host the neutrino detector. "Preparing a new site means a further delay of one year to a project that has already lost four years due to environmental activism," he says.
Conservationists are pleased, however. "We are indeed relieved," says Tarsh Thekaekara, coordinator of the NBR Alliance, the group that spearheaded the campaign against building the neutrino observatory at Singara. The proposed Suruliyar site is also close to the Periyar tiger reserve, $\begin{array}{ll}\text { further delay of one year } & \begin{array}{l}\text { although not in a wildlife } \\ \text { corridor as the Singara site } \\ \text { to a project that has }\end{array} \\ \text { already lost four years." } & \begin{array}{l}\text { Thekaronara says that } \\ \text { enviruliyar may decide to }\end{array} \\ \text { challenge the new proposal. "We only }\end{array}$ $\begin{array}{ll}\text { further delay of one year } & \begin{array}{l}\text { although not in a wildlife } \\ \text { corridor as the Singara site is. } \\ \text { to a project that has }\end{array} \\ \text { already lost four years." } & \begin{array}{l}\text { Thekarara says that } \\ \text { environmentalists near } \\ \text { Suruliyar may decide to }\end{array}\end{array}$

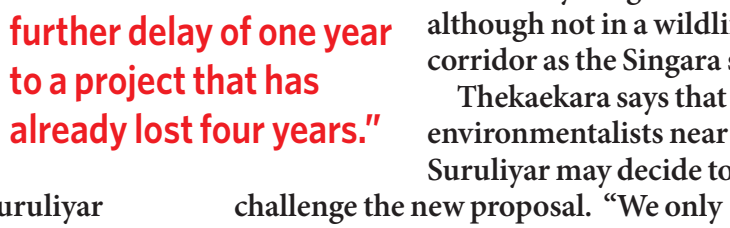

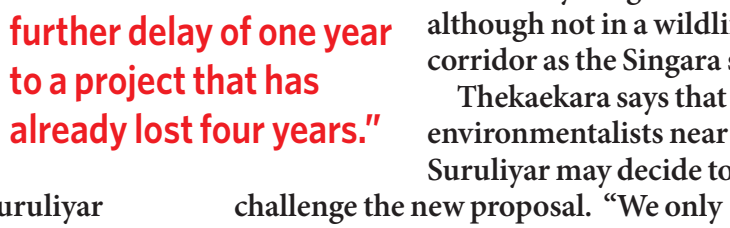
$\begin{array}{ll}\text { further delay of one year } & \begin{array}{l}\text { although not in a wildlife } \\ \text { corridor as the Singara site } \\ \text { to a project that has }\end{array} \\ \text { already lost four years." } & \begin{array}{r}\text { Thekaransays that } \\ \text { environmentalists near } \\ \text { Suruliyar may decide to }\end{array} \\ \text { challenge the new proposal. "We only }\end{array}$ challenge the new proposal. "We only
represent organizations in Nilgiri," he says. "It may happen that some of the members also active in [Suruliyar] will protest if there is a serious threat to nature." Mondal says that work at the new site will start only after all government clearances are in place. K. S. Jayaraman 